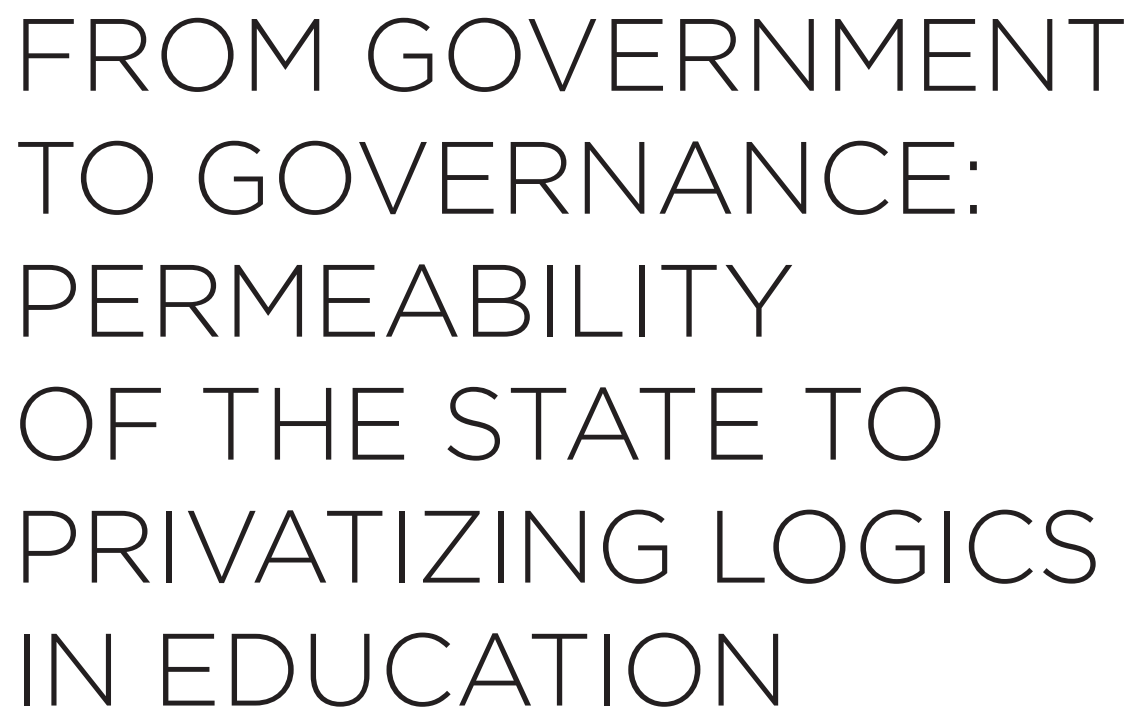

ZARA FIGUEIREDO TRIPODI'

SANDRA ZÁKIA SOUSA"

TRANSLATED BY Ana Paula C. Renesto"I

\title{
ABSTRACT
}

This article presents the notion of permeability as an analytical category for examining the privatization dynamics in current initiatives in early childhood, primary and secondary education. The concept of permeability refers here to the nature of relational patterns shaped in the implementation of educational policies. Therefore, the article examines two concomitant movements: on the one hand, public authorities' initiatives to assimilate and adapt knowledge developed in the private sector; on the other hand, the transfer of public services to private institutions. It also systematizes literature inputs which contribute to the understanding of the wide range of regulatory regimes. Initiatives that illustrate changes in the forms of Universidade Federal de Ouro Preto - UFOP Ouro Preto (MG), Brazil; zarafigueiredo@gmail.com management and provision of early childhood, primary and secondary education ॥ are discussed in light of these contributions. 

and of educational policies in particular lies in the need to resort to contributions to the understanding of the wide range of regulatory regimes that redefine public administration standards, welcoming the coexistence of initiatives located inside and outside the formal apparatus of the state.

These standards of public administration have been a central issue in the global agenda, guiding educational policies in different countries with governments of different political-ideological views. The reasons that have motivated governments to join this movement and the paths they have taken are formulated differently; however, over the last 30 years, privatization measures have increased, especially those related to the expansion of initiatives to publicize public services, implemented both by governments considered conservative and by those with a more progressive orientation. To illustrate this, consider the United Kingdom and the election of Tony Blair, from the Labour Party, in 1997, which, from the economic point of view, did not mean a rupture with the liberal principles that guided the previous governments of the Conservative Party of Margaret Thatcher (1979-1990) and John Major (1990-1997). Recent American history can also be seen from the same perspective given that Democrat Bill Clinton's election to the White House did not mean a retreat from the American public management standard either, especially in education, compared to the Republican governments that preceded it. Nor did the administration of Barack Obama, from 2009 
to 2017, represent a rupture with previous management logics in the educational field, especially with regard to privatization.

In Brazil, the election of Lula, from the Workers' Party, in 2002, and his re-election in 2006, as well as that of Dilma Rousseff, from the same party, in 2010 and 2014, did not translate into government initiatives that discontinued the guidelines adopted by public management since the early 1990s, in relation to both the logic of regulation and the interaction between the state and non-state actors, both in the formulation and in the implementation of social policies. The Lula administration's 2003 management plan, titled "Public Management for a Brazil of All”, ${ }^{1}$ as provided by Federal Law 11,079, 2004 (BRASIL, 2004), is educative in that sense, for already presenting, at that time, the intention to maintain an administrative logic of a managerial nature, implemented by Fernando Henrique Cardoso (1995-1998) in his first government. One of the guidelines of the PT (Partido dos Trabalhadores [Workers' Party]) government proposal announced the parameters that were supposedly demanded by contemporaneity and which would result in the promotion of public-private partnerships within the public administration.

Addressing the public and private boundaries in public management presupposes considering two movements that have been delineating concomitantly: on the one hand, initiatives of the public power to assimilate and adapt, to the state sector, the knowledge and management practices developed in the private sector; and, on the other hand, the transfer of the provision of public services to private for-profit or non-profit institutions. This means that, in the Brazilian case, since the 1990s, state reforms have sought to affect two distinct but closely related spheres: the management of policies within the formal apparatus of the state and the relationships and interactions established with the private sphere and with the "non-state public" sector (BRASIL, 1995), even recognizing public attributes in organizations and institutions external to the state apparatus.

In this sense, more than identifying the trend of privatization of the public, already widely pointed out in the literature, it seems important to inventory the processes behind this logic, which support it both from the point of view of society and of the state itself.

Therefore, this article presents the concept of "permeability of the state" as an important analytical category for examining recent experiences which illustrate these two logics of interaction between the state and initiatives external to it, focusing on early childhood, primary and secondary education: the appropriation of the private ethos by the management of early childhood, primary and secondary public education and the dispersion of the provision of such education to civil society actors.

Besides this introduction and succinct presentation of the work's methodology, the text discusses the concept of permeability of the state 
and organizes contributions from the literature on the notions of New Public Management and Governance, based on contributions from the fields of political science, public administration and relational sociology. Then, it links the notion of permeability and these two management trends in the educational field and illustrates the concepts discussed in light of current initiatives in Brazil.

\section{METHODOLOGICAL NOTES}

This article explores the privatizatizing logics that have underpinned public educational policies, through an empirical reconstitution of strategies used by state actors in the last decades. This qualitative work is based on a review of the literature on the notion of permeability of the state, as well as on the foundations of the New Public Management and Network Governance, aimed at identifying the theoretical currents from which the tools used by the state derive in the dissemination of private conceptions in the management and provision of public goods. The initiatives that make up the privatizing framework in Brazilian public education are illustrated with results of previous research, carried out by the authors, in which literature review, documentary research - and, in some cases, statistical tests - were used.

\section{PERMEABILITY OF THE STATE AS AN ANALYTICAL CATEGORY}

Studies on public-private relations have been developed in Brazil for several decades, from different perspectives. From the classic work of Sérgio Buarque de Holanda (1976), and the discussion proposed by Nunes (1987) on the political grammars of clientelism and corporatism in Brazil, to the studies developed by Marques (2000) on the permeability of the state, the literature has indicated that, although the privatization of the public occurs in various forms and logics, it is "true and visible to any observer" (MARQUES, 2000, p. 23).

In the field of educational policies, the discussion on the boundaries between the public and the private, in Brazil and elsewhere, has reported on their weakening, which leads to the change, it seems, in both classroom practices and the very formulation of policies (DALE, 1994; ADRIÃO; PERONI, 2008; ROBERTSON; VERGER, 2012; PERONI, 2013; BALL, 2014).

On the one hand, the phenomenon of privatization of the public, as a choice of governments, appears to be well-documented in research, with significant scientific evidence; on the other hand, as an analytical category, privatization still seems to require some effort for one to understand whether it is capable of apprehending the various 
forms and patterns of relation in the designs of current policies. This may be due to the fact that, conceptually, the notion of privatization tends to emphasize forms of intermediation of interests which focus on aspects more directed to lobbies between the private sphere and the state, leaving behind other factors which would motivate such partnerships. In other words, it seems that one of the central premises of the discussion about privatization, especially in the context of public educational policies, is the transfer of public resources to the private sector, which tends to restrict the analysis of their conditioning factors to issues of an economic nature.

The conception that guides this work starts from the recognition that an important analytical task for the discussion of the logics of education privatization in Brazil, in the field of research, is to devise a theoretical-analytical instrument that can also examine other causal relations implied in the choice of the private sector as a management model for the public sector, or as a form of provision of social welfare. Therefore, the concept of permeability of the state is used here as an analytical path.

In the Brazilian case, the notion of permeability goes back to the 1970s, when the then-sociologist Fernando Henrique Cardoso used it in a pioneering way, to address the "political aspects of planning" in Brazil and to discuss the existence of "circles of interest organized into rings" in the production of policies. For Cardoso, privatist interests flow, in their relations with the state, through webs of diffuse personal complicities,

\footnotetext{
[...] more oriented to relations and personal loyalties that make the city councilor, the deputy, the employee of a tax office, the industrialist, merchant or banker, the minister, and perhaps even the president him/herself accomplices. (CARDOSO, 1987, p. 179, free translation)
}

The author also draws attention to the fact that these are not necessarily lobbies, given that they suppose "a high degree of organization of the groups interested in a decision and rationality in the definition of objectives and means" (CARDOSO, 1987, p. 179, free translation). In the discussion proposed by Cardoso (1987), it is clear that the intermediation of interests in Brazil, in the sphere of production of public policies, at least at that time, was related to several factors, including those of affective and vicinal orders.

In the 1990s, Melo (1993) also used the concept of permeability to examine the intermediation of interests in the implementation of social policies in the post-1988 period. However, this interpretive key has become more present and stronger in the analysis of public policies since the works of Marques (1999, 2000), which investigated social networks in urban policies in Rio de Janeiro and the patterns related 
to their structuring. Marques not only examined the implementation of policies, but also offered a broader definition of the concept of permeability, which, according to the author, can be understood as:

\begin{abstract}
[...] a form similar to that described by the categories of bureaucratic rings, lobbying, and privatization of the state. Although the general idea of the concepts is similar, their specification makes numerous differences clear. Permeability is produced through a web of relationships and complicities, built over the life of individuals, incorporating different types of link. Contrary to what would be predicted by the direct use of a lobby-based perspective, for example, money is just one of the types of bonds between individuals and groups. (MARQUES, 2000, p. 53, free translation)
\end{abstract}

Another important dimension of the notion of permeability brought by Marques (2000) relates to the effects of the meeting or overlap of the state and the private sector in the various stages of the production and delivery of public policies. Such effects may assume different contours depending on the relational pattern established at a given moment, under certain historical, social, political, and economic conditions. This is due to the fact that permeability in itself is "perennial in time and present in all fields of the action of the state" (MARQUES, 2000, p. 53, free translation) and, therefore, its potentiality is realized (or not) in terms of the concrete material conditions encountered by policymakers, of the conceptions of state assumed by the group that is in power for a certain period, as well as in terms of the definitions of the functions of the state vis-à-vis society, of the dependence of the trajectory of certain policies, besides the very dynamics of accumulation of capital in contemporaneity, and the political game in a democracy.

In this sense, the analytical category permeability presents a significant potential for examining both the privatizatizing strategies and logics mobilized by different social and political actors, within the public administration, and their possible reasons. This is because the initiatives of the public power to assimilate and adapt, to the state sector, the knowledge and management practices developed in the private sector, and also to transfer the provision of public services to private for-profit and non-profit institutions, are related to the extent of

In this article, it was decided that both New Public Management and Network Governance would be treated as administrative trends, since we understand that, rather than a theoretical school they are programs that contain rules and techniques of how to manage. the permeability of the state and the search to understand the factors that motivated the potentiality of this permeability.

In the Brazilian case, these two dimensions of privatization have proved to be consistent with the principles of the two administrative trends that are now widely disseminated in several countries, ${ }^{2}$ including Brazil: New Public Management and Network Governance. 


\section{STRUCTURING PRINCIPLES OF NEW PUBLIC MANAGEMENT}

Regarding public administration and the forms of regulating its policies, the 1980s were marked by a wave of reforms based on the principles of New Public Management (NPM) mainly in member countries of the Organization for Economic Co-operation and Development (OECD). ${ }^{3}$

On the one hand, New Public Management was, in Western democracies, one of the most impressive trends in public administration (HOOD, 1991); on the other hand, managerialism is far from being affirmed as a management paradigm, or from constructing a satisfactory answer to the problems of societies as different as those which it entered. This means that the design of policy management and regulation, in the context of New Public Management, is highly path dependent, that is, although several countries use its principles, the results of their use are largely determined by the political and institutional design of each context, by the prevailing legal rationality, and by the political culture and tradition, understood in this case as the conceptions of state.

In any case, the principles of NPM derive from two theoretical currents: Administration and New Institutional Economy. The former concerns the introduction, in the public sphere, of methods and tools typical of the private sector, emphasizing the creation of standards of performance measures, results-based management, and customer focus. The New Institutional Economy emphasizes the implementation of incentive structures in the public service provision, and therefore introduces the logic of market competition. The division of the state bureaucracy between policymakers and the so-called front bureaucracies that implement them, emphasis on competition fostered by contractual logic and the quasi-market, as well as customer choice theory are also legacies of this school (HOOD, 1991; 1995; RHODES, 1996; 1997; ABRUCIO, 1996).

Examining the OECD countries that have moved towards New Public Management since the 1980s, Hood (1995) acknowledges that Sweden, Canada, New Zealand, Australia, and the United Kingdom are the ones that had most heavily incorporated managerial guidelines into their administrations. At the other extreme, Germany, Greece, Spain, Switzerland, and Japan have used the lowest levels of managerial tools. Performance pay, for example, which is one of the important tools in the logic of New Public Management, had been widely used since the 1990s in the United Kingdom, Denmark, Sweden, and New Zealand, while in Germany, as a result of the legislation providing for isonomy in public sector compensation, it has not been adopted (HOOD, 1995).

This classification of countries with high and low levels of adherence to principles of managerialism brings to the discussion at least two aspects already briefly announced. The first aspect is that

In this text, the terms New Public Management (NPM) and managerialism are used as synonyms. 
its adoption cannot be explained solely in terms of the orientation of political party ideologies, given that some social democratic countries with sound social protection systems have assimilated more incisive management guidelines, as is the case of Denmark and Sweden, while in others, such as Norway and Finland, the degree of assimilation is lower than that of their Scandinavian neighbors. There are countries, like Japan, which, despite being considered economically liberal, have adopted few directions of NPM (HOOD, 1995; MØLLER; SKEDSMO, 2015). The second aspect is the recognition that, even within a cluster of countries with high or low level of managerial reform, there are different degrees of policy implementation, that is, the direction of change cannot be understood in the same way. In addition, some countries rely more on NPM principles bequeathed by the theoretical school of administration, while others rely more on contributions from the new institutional economy.

\section{NEW PUBLIC MANAGEMENT IN THE BRAZILIAN CONTEXT}

The reformist wave experienced by the advanced capitalist countries, which began in the 1980s, but intensified mainly in the 1990s, was also felt in Brazilian lands. In Brazil, a significant date for the efforts to construct a Managerial State is 1995, which corresponds to the first government of President Fernando Henrique Cardoso (1995-1998), when the Ministry of Administration and State Reform was created under the command of the then minister, Luiz Carlos Bresser-Pereira. Its function, according to the idealizer of the reformist project, would be to create the conditions for the government to increase its governance, understood as the "ability to efficiently implement public policies” (BRASIL, 1995, free translation).

The basic assumption underlying the reformist project of Bresser-Pereira (1998, p. 12 and 9, free translation) was that the crisis that had begun to emerge in the 1970s and had become known in the mid-1980s was a crisis of the state, more precisely of the interventionist state, unlike that of the 1920s and 1930s, which had arisen from the market malfunctioning, a market which "the state was [supposedly] not able to satisfactorily regulate," which led "capitalist economies to chronic insufficiency of aggregate demand.” For Abrucio (2006), the state crisis directly affected the organization of public bureaucracies that had fewer resources and "more to do." The need to increase government efficiency led to reconsidering the bureaucratic model, which was thought to be slow and too attached to procedures and standards. The principles of impersonality, neutrality and rationality of public administration, which proved to be relevant to the states in another historical moment, marked by patrimonialism and clientelism, came to 
be understood from another angle, acquiring other meanings in face of the "kind of state that was beginning to crumble amid the crisis of the 1970s” (ABRUCIO, 2006, p. 175, free translation).

In this sense, contemporaneity, with its new forms of production, marked by the information revolution (LOJKINE, 1999) and by increasing demands for public services, stemming to a certain extent from groups that began to have relative vocalization power thanks to the Citizen's Constitution of 1988, supposedly required a more flexible public administration, a lighter state apparatus, which required the introduction of measures guided by managerial initiatives, in order to modify, as broadly as possible, the parameters of the bureaucratic organization (ABRUCIO, 2006).

Based on this diagnosis, Brazil discussed the incorporation of instruments from the New Public Management, with emphasis on the following guidelines: (i) state action for the "customer-citizen"; (ii) priority given to the control of results through contractualization; (iii) separation of centralized public policy-making departments and the decentralized units which implement those policies; (iv) transfer of competitive social and scientific services to the non-state public sector; and $(\mathrm{v})$ the formation of quasi-markets for managed competition to occur (BRASIL, 1995).

At the organizational structure level, decentralization and reduction of hierarchical levels became essential, since public administration should be permeable to more meaningful participation by private actors and/or civil society organizations, and it was necessary to shift the emphasis on procedures (means) to results (ends) (BRASIL, 1995).

The managerial logic, which would be the basis for public administration, was regulated by Constitutional Amendment 19, 1998 (BRASIL, 1998), and was made explicit in the caput of article 37, which adds the principle of efficiency to that of legality, impersonality, morality, and publicity, hitherto contained in the Constitutional Charter.

Although the cycle of managerial reforms in public administration which had began at the federal level in 1995 was discontinued in the second term of Fernando Henrique Cardoso (1998-2002), for having encountered resistance not only among public servants, but also within the government itself, as well as in Congress, the main ideas that supported such reforms gained momentum in federated units which, concurrently or not with federal government, began their cycles of reform (ABRUCIO, 2006).

\section{NETWORK GOVERNANCE}

One of the first and most important authors to have addressed the issue of network governance, R. A. W. Rhodes (1996), always points to 
the indiscriminate use of the term governance. For the author, taking governance as a synonym of government is a conceptual mistake, since the very concept of governance supposes a change in the notion of government as the central actor responsible for producing public policies, that is, as the welfare state. This is because, according to the Rhodes, the principle of overcoming the state and market dichotomy is postulated at the heart of the definition of governance, by means of introducing a new standard of cooperation between social actors, who are located outside the state apparatus, materializing as civil society. The sense of governance is thus related to a set of governmental efforts made in various forms and also by different political or social, public or private actors, at various levels of the public administration (KOOIMAN, 2003). Therefore, this is one of the meanings that made this administrative trend be called "network governance", after all, there is a dispersion of policy regulation towards actors outside the state apparatus, which metaphorically forms the sense of a network.

The arguments favorable to this logic were constructed from a certain recognition of the growing complexity of the social order, and its demands, which would presumably require a more flexible state capable of decentralizing functions, transferring responsibilities, and broadening the universe of the participating actors, without giving up the instruments of control and supervision (DINIZ, 1996). Ultimately, it is about considering that the performance of various actors in the provision of public policy tends to generate an optimal result, since these actors supposedly have more capillarity than the state itself to understand and reach certain social groups and their demands.

If network governance corresponds to the existence of multiple actors operating in the regulation and provision of public services and the presence of a state whose main role is to control expected previously contracted results, certainly the principles of New Public Management, such as competition, emphasis on results, customer focus, and performance measurement are relevant to the discussion on governance. After all, the transformation of the public sector involves less government and more governance, that is, the state assumes a policy control function and, to perform it, these managerial principles supposedly prove efficient.

The potential of the 1995 Brazilian reformist design to create the necessary conditions to introduce managerial principles and stimulate the notion of network governance, assumed as the interaction between state and societal actors in the provision of public policy, needs to be examined from two strands: the conceptual model developed by former minister Luiz Carlos Bresser-Pereira, Plano Diretor de Reforma do Aparelho de Estado (PDRAE - Master Plan for Reform of the State Apparatus) 
(BRASIL, 1995) and the change in the constitutional normative standard, regarding the norms and rules of the public administration.

The conceptual model that underpins the reformist model proposed by Bresser-Pereira distinguishes the segments considered fundamental by the author for the action of the state and divides the state apparatus into four sectors, to which certain forms of property correspond. There is state and private property, and to these two is added a third one, called non-state public property, which consists of non-profit organizations (BRASIL, 1995).

From the point of view of the normative standard, Constitutional Amendment 19/1998 created a favorable legal environment for some of the main guidelines of the New Public Management, such as management contracts, to be implemented. Contractualisation would become a privileged instrument to establish forms of relationship between ministries or departments within the state apparatus, as well as between the state and societal actors, in the perspective of a results-oriented administration, with targets and indicators established and demanded from public managers and civil society organizations, which would theoretically make new forms of accountability feasible.

Based on the examination of the proposed conceptual model, Figure 1 is a diagram for the field of public early childhood, primary and secondary education.

\section{FIGURE 1}

CONCEPTUAL MODEL OF PDRAE (1995) APPLIED TO EDUCATION

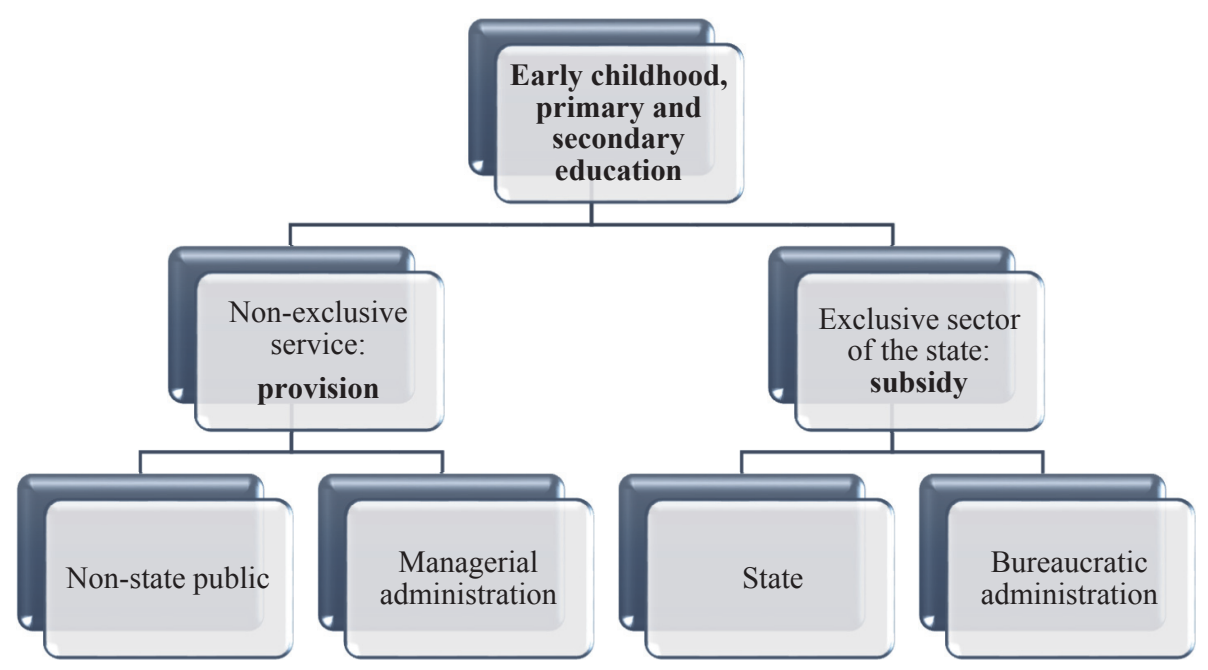

Source: Authors' development, based on data from PDRAE (BRAZIL, 1995).

According to PDRAE, early childhood, primary and secondary education, as a subsidy, appear linked to the exclusive sector of the state, which privileges the form of bureaucratic administration; whereas its provision, once included in the sector of non-exclusive 
services of the state or competitive sector, could be effected via nonstate public property, in which the managerial model of administration is considered appropriate for the management of the policy.

Since it was included in the competitive or non-exclusive sector of the state, the choice of the managerial administration would be the most adequate, according to its proponents, because it incorporates tools and logics of private management into the educational area, which would supposedly increase the efficiency of the system and the quality of education and enable the permeability of new actors in educational policy, in terms of its provision.

In this sense, a new legal framework is established to regulate the non-state public sphere, replacing the public utility title, governed at the federal level by Law 91, of 1935 (BRASIL, 1935), and amended over the years in some respects. The new legal titles for civil society entities of public purposes are conceived as instruments with greater potential to reorder the relations between the state and society, the state and the market, and thus the public and the private.

Organizações Sociais (O.S. - Social Organizations) began to compose the "forces alternative" to the state, as a direct provider of social services, disciplined at the federal level by Law 9,637, of 1998, and Law 9,790, of 1999 (BRASIL, 1999), which, also at the federal level, changes the legal framework of third sector organizations, with the legal figure of Organizações da Sociedade Civil de Interesse Público (OSCIP Civil Society Organizations of Public Interest). More recently, Law 13,019, of 2014 (BRAZIL, 2014), completes the regulatory cycle of the third sector, by establishing the legal framework for partnerships between the public administration and civil society organizations, in a system of mutual cooperation, for the achievement of public interest purposes, with the possibility of operating in networks. It is also worth highlighting the recognition, by the Federal Supreme Court, in 2015, of the constitutionality of the OS in the provision of public social services, within the Direct Unconstitutionality Action 1,393/DF (BRASIL, 2015).

\section{PERMEABILITY OF THE STATE TO THE PRINCIPLES OF NEW PUBLIC MANAGEMENT IN EDUCATION}

Since the mid-1990s, there have been attempts to restructure the regulatory logic of public early childhood, primary and secondary education; however, there has not been a radical change in the principles of provision of this first social right provided, in such terms, by article 6 of the Federal Constitution (BRASIL, 1988). The notions of administrative, educational and financial decentralization, widely disseminated in the early 1990s, were one of the first steps towards the reordering of the design of educational public policies in Brazil. 
Decentralization at that time meant above all improving the democratic capacity of the country, which, supported by strong popular participation, was making its transition to a civilian government. The positive association between decentralization and democracy was also felt in the educational field. Some state governments elected in 1982 attempted to construct democratic practices in education, as was the case of the Tancredo Neves government in Minas Gerais, which not only organized a State Department of Education with actors from the educational debate and committed to progressive conceptions for the area, but also fostered important education forums with broad participation of civil society. ${ }^{4}$

However, less than a decade after the Citizen's Constitution was enacted, there arose a certain consensus that the economic crisis that was then felt in Brazil, since the second half of 1990, was a crisis of the current state model and, therefore, it would be necessary to redesign it. In that scenario, the strong decentralization trend, as a synonym for the democratization of school processes and the autonomy of educational systems, in financial, educational and administrative terms, began to assume contours of deconcentration, of transfer of responsibilities to the education systems and their respective schools, but without providing education with equivalent financial contributions or working conditions (ROCHA, 2011). Concomitantly with the process of conceptual and practical re-signification of decentralization, strengthened within the framework of state reform, the low quality of teaching that the public school had been providing over time was reiterated.

In this context of transfer of responsibilities and an attempt to improve educational indicators, understood as quality in education, the Brazilian state became "permeable" to "instruments of public action" aimed at introducing the logic of private management into the public sphere.

According to Lascoumes and Galès (2012, p. 21, free translation), "instruments of public action" are the techniques, means of operation, devices "that allow materializing and operationalizing the governmental action", which therefore are not

\section{[...] axiologically neutral and indifferently available tools. They are, on the contrary, sponsors of values, fed by an interpretation of so- cial issues and by specific conceptions of the form of regulation envisaged.}

In this direction, large-scale student performance evaluations began to play a central role in public educational policies (SOUSA; OLIVEIRA, 2010). In 1990, the Sistema de Avaliação da Educação Básica (SAEB - Early Childhood, Primary sand Secondary Education Evaluation 
System) conducted its first sample application in public schools and, in 1995, a new methodology for constructing the test and analysis of results, the Item Response Theory (IRT), was adopted, opening the possibility of comparability between the results of evaluations over time, combining sample and census designs. It is true that large-scale evaluations are not in themselves linked to this or that management logic; however, it is no less true that evaluations, in terms of their uses and misuses, have become a privileged instrument of public action to introduce managerial principles in education. The possibility of comparing results, by means of IRT and census evaluations, is in line with the logic contained in PDRAE, according to which education, as non-state public property considered as a competitive activity, must be regulated by managerial administration.

Although the literature has already shown that, since the 1930s, it was sought to construct an evaluation system in Brazil (FREITAS, 2007), the innovations brought by IRT, the creation of Prova Brasil in 2005, a census exam within SAEB, followed by the creation of Índice de Desenvolvimento da Educação Básica (IDEB - Early Childhood, Primary and Secondary Education Development Index), in 2007, have become important tools for the implementation of managerial guidelines in education, as they sought to assimilate and adapt, to the state sector, managerial knowledge and practices developed in the private sector, announcing attempts to transform the pattern of regulation of education policy in Brazil.

IDEB has made possible not only the development of performance scales for all Brazilian students, but also their subsequent dissemination, largely oriented by comparisons and disaggregated by states, municipalities, networks, and schools.

The measurement of this performance created the necessary conditions for states and municipalities, if they so wished, to contractualize goals between education departments and their respective schools with different material or symbolic consequences (BONAMINO; SOUSA, 2012). Thus, education systems started to introduce, into their educational policy, incentive structures, translated into bonuses for teachers, productivity awards by teams and $14^{\text {th }}$ month salaries. ${ }^{5}$

The initiatives of differentiated pay to teachers, underway in Brazil, usually fail to affect the career and salary structure of the teaching profession, which traditionally take into account years of experience and training as the main factors for progression (BAUER; SOUSA, 2013). However, there are propositions that go in that direction, like the one disseminated by OSCIP Parceiros da Educação [Partners of Education], which, in a text published on its website, links academic stability to low educational performance in terms of student achievement. According to the OSCIP, "the current teaching career has lamentable misconceptions that, in addition, are politically difficult to be solved", 
hence the need to create "a new parallel and voluntary career", with consequent "termination of the contracts effected by means of concurso público" (PARCEIROS DA EDUCAÇÃO, 2010). ${ }^{6}$

At the root of this managerial tool, which consists of rewarding and/or sanctioning schools or their teachers, is the notion of creating an environment conducive to competitiveness that would supposedly lead to greater efforts to increase the quality of education, understood as student performance in large-scale evaluations.

These instruments are linked to the theoretical assumptions of the New Institutional Economy, especially the Agency Theory, which accounts for most of the tools used in the scope of New Public Management. In very general terms, and therefore running the risk that any reduction entails, in this perspective, there is a search for the formulation of an ideal contract between two actors, with divergent interests at first: the principal and the agent. In the relationship, the latter [agent], who in the educational case may be the teacher, has certain information that the principal [the secretary of education] does not have or does not observe directly. In addition,

\section{[...] the agents know what motivates them, they have privileged knowledge about their capabilities, and may have the chance to observe things that the principal cannot see, even performing some actions without full or any knowledge of the principal. (PRZEWORSKI, 2006, p. 45)}

Therefore, the incentive structure would lead the agent to act in defense of the interests of the principal, in this case, the policy makers.

Although the use of the agency theory presents constraints when transposed to the public sector, which will not be discussed in this paper, its presuppositions are limited to the recognition by policymakers of the existence of information asymmetry between the actors involved in its implementation and the assumption that the policy formulated has great potential to be transformed through the appropriation and re-signification by front-line workers or "streetlevel bureaucrats" (LIPSKY, 1980).

In any case, it should be recognized that managerial regulation has, to a greater or lesser degree, marked the most recent political choices in early childhood, primary and secondary education in Brazil. 


\section{PERMEABILITY OF THE STATE TO NEW ACTORS IN THE PROVISION OF EARLY CHILDHOOD, PRIMARY AND SECONDARY EDUCATION}

Examining the 1990s and 2000s allows identifying the new characteristics imposed on the field of educational policies, which, it seems, express deeper trends of change and possibly a reordering of the bases of the Brazilian welfare state regarding education; such reordering can also be explained, to some extent, by the change in the conception of state until then in force and the questioning of its functions. Predominantly grounded on the principles of the New Public Management, the "innovations" that the field of educational policies has experienced over the last decades have been present in most of the capitalist, advanced or emerging countries, including the so-called social democrats. Certainly the effects of the use of instruments of public action of a managerial nature will tend to change more deeply the logic of education policies, depending on the type and form of the welfare state of each country. ${ }^{7}$

One of the premises of this study is that the managerial arrangements incorporated to the educational regulation in Brazil have created the necessary conditions for reordering the very roles of the state: from central and direct provider of educational services to regulator of the regulation. It is in this sense that the other privatizing face of education, previously mentioned, is expressed: the transfer of educational provision to private institutions, whether for profit or non-profit.

The permeability of the state to new instruments of public action corresponds to a certain strategic withdrawal of that state in the sphere of direct intervention and the entry of new actors, located outside the state apparatus, into the provision of educational services, which has been called network governance (KOOIMAN, 2003; RHODES, 1996, 1997; GOLDSMITH; EGGERS, 2011). However, this strategic withdrawal must be understood in the terms advocated by PDRAE, that is, the state moves towards a withdrawal from being the only actor responsible for the direct provision of education, but it continues to be a "subsidiary state", after all, via subsidy, the state creates the ideal conditions for the “educational market” (DALE, 1994).

In this scenario, the entry of societal actors, "in partnership" with the state, would fulfill the function of diversifying provision, increasing the range of choice and creating competition, which, for the defenders of managerialism, would produce a certain quality and, from the liberal perspective, guarantee parents' right to choose, reducing the levels of state interference over the individual.

Network governance, understood as the interaction between the state and civil society, in the form of partnerships, for the delivery of services of a social nature to the population, including education, is not something new in Brazil. Child care, in day care centers, for example, 
has historically been carried out by community and/or philanthropic entities, which allows stating that, to a large extent, the expansion of the service of this educational stage has occurred outside the state sphere, at least in terms of the institution that provides it.

The provision of higher education has also expanded, especially since the year 2000, through partnerships with the for-profit private sector, under Programa Federal Universidade para Todos (PROUNI-University for All Federal Program). From this movement of interaction between the state and actors located outside the state apparatus, whether for profit or non-profit, in the educational provision, one can deduce that it has historically occurred in the stages and levels of education considered not legally compulsory.

However, this movement has been changing substantially in two respects. The first one concerns the reach of partnerships in terms of level and educational modality. Whereas network governance was limited, in terms of the target audience, to attending to both ends of the school cycle (child day care and higher education), more recently, the privatization process has led private actors to also work in the service to compulsory levels, such as secondary education (for 14 to 17 year-olds when there is no age-grade distortion), pre-school education, and vocational education.

The second respect is related to the change that has occurred in the relational pattern on which network governance is based. This means that the provision logic structured under a multiplicity of entities invariably leads to various education projects, given that the third sector consists of a range of institutions with different characteristics, with different legal forms and can, therefore, have different effects on education, from both the political administrative and the political educational perspectives.

The analytical framework of the statement above is simple. By entering into a partnership with a civil society entity, through institutes such as "Term of Cooperation" or "Term of Development" ${ }^{8,9}$ the state allows, in the limit, the design of the educational policy to remain under its tutelage, as well as its relative regulatory capacity. In other words, it can be affirmed, at least from the legal point of view, that the performance of civil society in these cases is of development (fomento). The same can be said, to a certain extent, of the partnerships signed between the state and entities certified as OSCIP. The case of the institutions that receive the title of OS is quite distinct and has significant potential to impact educational policies. This is due to the fact that the legal framework establishing the OS, Federal Law 9,637/1998 (BRAZIL, 1998, free translation), provides, in article 20, the possibility of "absorbing activities carried out by public entities or bodies of the federal government”. In the case of the OS, there is a clear de Fomento.

\section{9}

Federal Law 13,019/2014 extinguishes the figure of agreement (convênio) as a legal institute to celebrate partnerships between the state and entities and social organizations. According to the legal framework, the agreements continue to be instruments of partnership, but only between federated entities, as provided in article 84 of that law. 
intention to transfer activities formerly performed by public bodies to entities qualified as OS, giving rise to a "legal entity of private law not included in the concept of Public Administration, whether direct or indirect" (DI PIETRO, 2015, p. 278, free translation). In other words, the network woven by the state with entities qualified as OS at the federal level enables non-state actors not only to provide education, but also to decide on the design and regulation of the educational policy in question, which results in the extinction of the public sector that previously provided the service. Di Pietro warns of this form of partnership, drawing attention to its effects. For the author:

The fact that a social organization absorbs activity carried out
by a state entity and uses public patrimony and public servants
that were before at the service of this entity, which is now extinct,
leaves no doubt that, under the guise of a private entity, the real
objective is to mask a situation that would in all respects be subject
to public law. (DI PIETRO, 2015, p. 280)

In this context, the most significant educational initiative is the one put into practice by the state of Goiás, initiated under the administration of governor Marconi Perillo, from the Brazilian Social Democracy Party (PSDB). The proposal of Goiás state is to initially transfer to the OS the management of 23 state schools, as can be seen in Decision 596/2015, authored by the governor:

Thus, in view of all that appears in the present case, and in compliance with the provisions of the sole paragraph of article 6 of State Law 15,503/05, with wording given by State Law 18,331/13, I consider it appropriate, in the exercise of my governmental competence, to determine the transfer of the management of state public schools to social organizations, by means of management contracts, in the strict terms of those established by the laws above and within the limits established by Decree $8,469 / 15$, for concluding that the measure proves to be appropriate to the service of the public interest. (GOIÁS, 2015, p. 3, free translation)

At the center of the debate brought by Decree 596/2015 are the reasons given by Goiás government for choosing to provide education through OS: the grades in IDEB and the cost per student.

It should be noted that the first reason made explicit to "legitimize" the political choice was IDEB, since the governor directly links the supposed increased spending on students and teachers to the "Direct effect on school scores in IDEB", and questions it: 
Management and economic viability, added to the current budget and financial constraints the state is experiencing - which are not exclusive to Goiás - have led me to seek an alternative measure to such high public expenditure through the full provision of teaching staff. In this regard, it should be noted that, based on a technical study carried out in the case (p. 633-641), the increase in expenditure per student or teacher has not had a direct effect on school grades in the Early Childhood, Primary and Secondary Education Development Index (IDEB) a factor that I consider relevant to the adoption of this public partnership policy. (GOIAS, 2015, p. 1, free translation)

This data confirms, to a certain extent, the thesis of this work, i. e., that the way the instruments are appropriated by the New Public Management creates the necessary conditions for the implementation of network governance; it also corroborates the premise of Lascoumes and Galès (2012) that these tools become instruments of public action with intentionalities, in terms of policies, and do not have the neutrality sought by its idealizers.

With regard to the student-year cost, the Decree is also very emphatic, drawing attention to the New Public Management principles taken to educational policy in that context:

[...] the State Department of Education, Culture and Sport [...] concluded that the average amount spent per student in a month in the state public school system is approximately $\mathrm{R} \$ 388.90$. In compliance with the principle of economic viability, and based on the idea that the private sector enjoys greater economic and administrative efficiency, it established that $\mathrm{R} \$ 350.00$ is the ceiling amount per student per month to be passed on to the private partner [...], with an economy of approximately 10\%, since the minimum amount is $\mathrm{R} \$ 250.00$. Entities interested in concluding a partnership agreement are to present work proposals within those financial limits; the Administration will select the entity whose program best meets the goals set and, at the same time, represents a lower expenditure of public resources, in compliance with the principle of economic viability, therefore, realizing the idea of value for money, so dear to the principles of the New Public Management. (GOIÁS, 2015, p. 3, free translation)

Although the Goiás State Department of Education, Culture and Sports received a formal "Recommendation" from Goiás Public Prosecutor's Office, ${ }^{10}$ the Federal Public Prosecutor's Office, and the Court of Audit, at the Court of Audit of Goiás State, ${ }^{11}$ and is the target

10

Translator's note: In Portuguese, Recomendação. It is an instrument used by the Public Prosecutor's Office to present factual and legal reasons on a particular issue, aiming to persuade the recipient to perform or to stop performing certain acts in order to improve public services and of public relevance, or respect for the interests, rights and assets defended by the institution. It is thus an instrument to prevent liability or correction of conduct. Available at: <http:// www.cnmp.mp.br/portal/ todas-as-noticias/10240publicada-recomendacaoque-disciplina-expedicaode-recomendacoes-pelo-mp ?tmpl=component\&pr int $=1 \&$ page $=>$. Access on: 29 Jan 2018.

11 Public Civil Action ICs 201500469399 and 201500468202 by Goiás Public Prosecutor's Office. 
of a Public Civil Action (Ação Civil Pública), proposed by the Goiás Public Prosecutor's Office (2016), government initiatives aimed at transferring state schools to private management have not lost momentum. Public calls $001 / 2017$ and $002 / 2017$ for the selection of OS to manage state schools are in progress.

Unless we are mistaken, this is one of the first experiences of compulsory education provision made possible by network governance, designed from the interaction of the state with OS.

Another initiative underway, within the scope of compulsory education provision, is that of the Federal District. In 2016, governor Rodrigo Rollemberg, from the Brazilian Socialist Party (PSB) announced the intention to expand early childhood education provision by means of vouchers. ${ }^{12}$ In June of that year, the Executive Power forwarded Bill of Law 1,177/2016 to the Legislative Chamber (DISTRITO FEDERAL, 2016), which established program Bolsa de Educação Infantil - Pré-escola (Early Childhood Grant - Preschool), for children aged 4 to 5 years, i. e., for the second stage of early childhood education, which is compulsory.

Article 5 provides that the Early Childhood Grant - Preschool is “paid directly to the partner educational institution”, and that R\$ 456.57 is the monthly amount of the grant per beneficiary, as established in the sole paragraph of article 6 .

In the case of the Federal District, however, the relational pattern is made effective in the form of "Term of Cooperation", which is supported by Law 13,019/2014 (BRAZIL, 2014), which institutes such term to substitute the agreement form (convênio), extinguished as a form of partnership between the state and civil society. In this form, the interaction between the actors is made effective as a development (fomento) activity, and the legal regulation of education remains under the responsibility of the state.

The path the Federal District has taken in this area is in line with data from previous research aimed to identify trends in the provision of early childhood education in Municipal Education Plans for the 2014-2024 decade. ${ }^{13}$ One of the research findings is that the Federal

announcement made by the Federal District governor was the subject of an article in the Education section of Folha de São Paulo newspaper on July 24 th, 2016

is postdoctoral research was carried out at the Centro de Estudos da Metrópole, Universidade de São, under the supervision of Prof. Marta Arretche. which was funded by the São Paulo Research Foundation - FAPESP Project 2015/14405-8
District was one of the federated entities that advanced the most to make explicit in its district plan that the provision would be made via third sector. In its 10-year document, the proposal for state-private interaction was no longer one of the strategies for achieving goal 1 (Early Childhood Education), of the District Education Plan - it had become the goal itself:

GOAL 1

Providing universal access, by 2016, to pre-school education for children aged 4 to 5 years and expanding the provision of early childhood education in public and contracted day care centers (creches conveniadas), in order to serve at least $60 \%$ of the 
The same research, which analyzed 169 Brazilian municipalities, through stratified random sampling, found that 73 municipalities made explicit in their Municipal Education Plans that, in order to fulfill the goal established by the National Education Plan, the expansion of early childhood education provision would take place via the third sector, in several forms: OS, OSCIP or in the extinct form of agreement (conveniamento).

This fact deserves attention, given that such documents are being taken as an expression of state policies and, therefore, as likely to remain in force over time, regardless of the alternations of governments in power. Therefore, it is plausible to suppose that network governance tends to become a permanent policy, at least in early childhood education.

\section{FINAL NOTES}

This article has aimed to discuss, through the analytical category permeability of the state, the privatizing logics that have governed public education policies in Brazil.

Although the concept of permeability is linked to other analytical aspects, such as privatization, publicization and intermediation of interest, it can significantly contribute to examining public-private relations because it points to a characteristic of the state field: its perennial ability to be crossed by other actors and interests, not necessarily motivated by reasons of economic order only.

This interpretative key proved important to the development of the work insofar as the examination of the privatizing path of the country in the educational field requires turning one's eyes to two dynamics that presuppose levels of porosity of the state fabric: (i) the appropriation by the public sector of a management logic of the private initiative that has materialized in "instruments of public action" (LASCOUMES; GALÈS, 2012), such as uses of large-scale evaluations to promote accountability policies, goal setting for schools based on student performance measures in standardized tests, in order to generate the so-called "managed competition"; and (ii) the provision of education by actors outside the state apparatus, especially those included in the so-called third sector or organized civil society.

Considering these two privatizing dimensions based on the analytical category permeability implies discussing them from a plural 
perspective which involves the recognition that the state is permeable to external actors and interests, to a greater or lesser degree, at different times, due not only to historical, economic, political factors, but also to strictly personal reasons.

In this sense, academic studies have pointed out that most Brazilian municipal entities have low state capacity, also understood, in the scope of this work, as the level of insulation of its bureaucracy (GOMIDE; PIRES, 2014; FARAH, 2001). This may lead certain sub-national units to be permeable to private processes - both in the form of management tools prescribed as possible generators of quality, and in the forms of educational provision - motivated even by reasons of a communal or affective nature. Certainly, the low tax and fiscal capacity of the states and municipalities is a strong explanation for the adoption of private strategies; however, disregarding other factors may lead to some analytical bias. Disregarding, for example, that the number of places in day care centers may have a positive correlation with political credit in electoral years and that this phenomenon may lead states to become more permeable to privatizing initiatives in these periods seems unproductive as an analysis option.

The systematization of some initiatives underway in Brazil, within the scope of the privatization process, points not only to a trend towards the intensification of the use of managerial tools, but also to the expansion of the educational provision by private actors in different legal forms, now including compulsory school levels.

Lastly, taking into account that the political option for a given educational provision entails a series of constraints - including the percentage of social spending "acceptable" for a particular government and the state conceptions that underpin that government -, it is plausible to suppose that, in the context of a New Tax Regime, with frozen social expenses, and of reformulation of secondary education, with an extension of the school hours and with part of the curriculum focused on technical training, with the possibility of the latter being taught by professionals with "notorious knowledge", the new forms, designed especially in the third sector sphere, are likely to become the protagonists in the direction of education. This remains to be checked.

\section{REFERENCES}

ABRUCIO, Fernando Luiz. O impacto do modelo gerencial na administração pública: um breve estudo sobre a experiência internacional recente. Brasília: Escola Nacional de Administração Pública, 1996. 52 p. (Cadernos ENAP, n. 10).

ABRUCIO, Fernando Luiz. Os avanços e os dilemas do modelo pós-burocrático: a reforma da administração pública à luz da experiência internacional recente. In: BRESSER-PEREIRA, Luiz Carlos; SPINK, Peter (Org.). Reforma do Estado e administração pública gerencial. Rio de Janeiro: Editora FGV, 2006. 
ADRIÃO, Theresa; PERONI, Vera (Org.). Público e privado na educação: novos elementos para o debate. São Paulo: Xamã, 2008.

BALL, Stephen J. Educação global S.A.: novas redes de políticas e o imaginário neoliberal. Tradução de Janete Bridon. Ponta Grossa: UEPG, 2014.

BAUER, Adriana; SOUSA, Sandra M. Zákia Lian. Avaliação e carreira docente: iniciativas da rede de ensino estadual paulista. Revista e-Curriculum, São Paulo, v. 11, n. 1, p. 201-215, abr. 2013.

BONAMINO, Alicia Catalano; SOUSA, Sandra Zákia Lian. Três gerações de avaliação da educação básica no Brasil: interfaces com o currículo da/na escola. Educação e Pesquisa, São Paulo, v. 38, n. 2, p. 373-388, abr.jjun. 2012.

BRASIL. Constituição da República Federativa do Brasil. 1988. Disponível em: <http://www.planalto. gov.br/ccivil_03/constituicao/constituicao.htm>.

BRASIL. Emenda Constitucional n. 19, de 04 de junho de 1998. Modifica o regime e dispõe sobre princípio e normas da Administração Pública, Servidores e Agentes políticos, controle de despesas e finanças públicas e custeio de atividades a cargo do Distrito Federal, e dá outras providências. Diário Oficial [da] República Federativa do Brasil, Brasília, DF, 1998.

BRASIL. Lei n. 91, de 28 de agosto de 1935. Determina regras pelas quais são as sociedades declaradas de utilidade pública. Disponível em: <http://www.planalto.gov.br/ccivil_03/leis/19301949/L0091.htm>.

BRASIL. Lei n. 9.637, de 15 de maio de 1998. Dispõe sobre a qualificação de entidades como organizações sociais, a criação do Programa Nacional de Publicização, a extinção dos órgãos e entidades que mencionam e a absorção de suas atividades por organizações sociais, e dá outras providências. Diário Oficial [da] República Federativa do Brasil. Brasília, DF, 1998.

BRASIL. Lei n. 9.790, de 23 de março de 1999. Dispõe sobre a qualificação de pessoas jurídicas de direito privado, sem fins lucrativos, como Organizações da Sociedade Civil de Interesse Público, institui e disciplina o Termo de Parceria, e dá outras providências. Diário Oficial [da] República Federativa do Brasil, Brasília, DF, 1999.

BRASIL. Lei n. 11.079, de 30 de dezembro de 2004. Institui normas gerais para licitação e contratação de parceria público-privada no âmbito da administração pública. Diário Oficial [da] República Federativa do Brasil, Brasília, DF, 2004.

BRASIL. Lei n. 13.019, de 31 de julho de 2014. Estabelece o regime jurídico das parcerias voluntárias, envolvendo ou não transferências de recursos financeiros, entre a administração pública e as organizações da sociedade civil, em regime de mútua cooperação, para a consecução de finalidades de interesse público; define diretrizes para a política de fomento e de colaboração com organizações da sociedade civil; institui o termo de colaboração e o termo de fomento; e altera as Leis n. 8.429, de 2 de junho de 1992, e 9.790, de 23 de março de 1999. Diário Oficial [da] República Federativa do Brasil, Brasília, DF, 2014.

BRASIL. Ministério de Administração e Reforma do Estado - Mare. Plano Diretor da Reforma Administrativa do Aparelho do Estado. Brasília, DF: Mare, 1995.

BRASIL. Supremo Tribunal Federal, Tribunal Pleno. ADI n 1.393. Relator para o acórdão Min. Luiz Fux. Julg. 5.5.2015. Acórdão pendente de publicação.

BRESSER-PEREIRA, Luiz Carlos. A reforma do Estado dos anos 90: lógica e mecanismos de controle. Lua Nova, São Paulo, n. 45, p. 49-95, 1998.

CARDOSO, Fernando Henrique. Aspectos políticos do planejamento. In: LAFER, Betty Mindlin (Org.). Planejamento no Brasil. São Paulo: Perspectiva, 1987.

DALE, Roger. A promoção do mercado educacional e a polarização da educação. Educação, Sociedade e Culturas, Porto, n. 12, p. 109-139, 1994.

DINIZ, Eli. Governabilidade, governance e reforma do estado: considerações sobre o novo paradigma. Revista do Serviço Público, Brasília, ano 47, v. 120, n. 2, maio/ago. 1996.

DI PIETRO, Maria Sylvia Zanella. Parcerias na administração pública: concessão, permissão, franquia, terceirização, parceria público-privada e outras formas. São Paulo: Atlas, 2015. 
DISTRITO FEDERAL. Plano Distrital de Educação. Diário Oficial do Distrito Federal. Brasília, DF, 15 jul. 2015. p. 2.

DISTRITO FEDERAL. Mensagem n. 113/2016-CAG. Brasília, DF, 21 jun. 2016.

DRAIBE, Sônia Miriam. O welfare state no Brasil: características e perspectivas. Campinas: Unicamp/NEPP, 1993. 57 p. (Caderno de Pesquisa, n. 8).

FARAH, Marta Ferreira Santos. Parcerias, novos arranjos institucionais e políticas públicas no nível local de governo. RAP - Revista de Administração Pública, v. 35, n. 1, p. 119-145, jan./fev. 2001.

FONSECA, Nelma Marçal Lacerda. Entrevistando Neidson Rodrigues. Revista Brasileira de Educação, Rio de Janeiro, n. 22, p. 148-168, abr. 2003. Disponível em: <http://www.scielo.br/ scielo.php?script=sci_issuetoc\&pid=1413-247820030001\&lng=en\&nrm=iso $>$. Acesso em: 17 jun. 2017.

FREITAS, Dirce Nei Teixeira de. A avaliação da educação básica no Brasil: dimensão normativa, pedagógica e educativa. Campinas, SP: Autores Associados, 2007.

GOIÁS. Ministério Público do Estado. Inquérito Civil Público n. 01/2016. Anápolis, Goiás: MPE, 2016.

GOIÁS. Secretaria da Casa Civil. Despacho n. 596, de 8 de dezembro de 2015. Diário Oficial do Estado. Goiânia, 8 de dezembro de 2015.

GOLDSMITH, Stephen; EGGERS, Willian D. Governar em rede: o novo formato do setor público. Brasília: Enap, 2011.

GOMIDE, Alexandre de Ávila; PIRES, Roberto Rocha C. Capacidades estatais e democracia: a abordagem dos arranjos institucionais para análise de políticas pública. Brasília: Ipea, 2014.

HOOD, Christopher. A public management for all seasons? Public Administration, v. 69, n. 1, p. 3-19, 1991.

HOOD, Christopher. The new public management in the 1980s: variations on a theme. Accounting, Organizations and Society, v. 20, n. 2-3, p. 93-109, 1995.

KOOIMAN, Jan. Governing as governance. Thousand Oaks, CA: Sage, 2003.

LASCOUMES, Pierre; LE GALÈS, Patrick. A ação pública abordada pelos seus instrumentos. Revista de Pós-Graduação em Ciências Sociais, v. 9, n. 18, jul./dez. 2012.

LIPSKY, Michael. Street-level bureaucracy: dilemmas of the individual in public service. New York: Russell Sage Foundation, 1980.

LOJKINE, Jean. A revolução informacional. São Paulo: Cortez, 1999.

MARQUES, Eduardo Cesar. Redes sociais e instituições na construção do Estado e da sua permeabilidade. Revista Brasileira de Ciências Sociais, São Paulo, v. 14, n. 41, p. 45-67, out. 1999.

MARQUES, Eduardo Cesar. Estado e redes sociais: permeabilidade e coesão nas políticas urbanas no Rio de Janeiro. Rio de Janeiro: Revan; São Paulo: Fapesp, 2000.

MELO, Marcus André. Anatomia do fracasso: intermediação de interesses e a reforma das políticas sociais na Nova República. DADOS, n. 36, p.119-163, 1993.

MØLLER, Jorunn; SKEDSMO, Guri. Nova gestão pública na Noruega: o papel do contexto nacional na mediação da reforma educacional. Educação e Sociedade, Campinas, v. 36, n. 132, p. 779-800, jul./set. 2015.

PARCEIROS DA EDUCAÇÃO. Propostas transformadoras para melhoria da qualidade do ensino básico. São Paulo: Parceiros da Educação, 2010. Disponível em: <http://www.parceirosdaeducacao.org. br/evento_propostas/pdf/transformacao.pdf>. Acesso em: 11 ago. 2017.

PERONI, Vera Maria Vidal. As relações entre o público e o privado nas políticas educacionais no contexto da terceira via. Currículo sem Fronteiras, v. 13, n. 2, p. 234-255, maio/ago. 2013. 
PRZEWORSKI, Adam. Sobre o desenho do Estado: uma perspectiva agent x principal. In: BRESSER-PEREIRA, Luiz Carlos; SPINK, Peter (Org.). Reforma do Estado e administração pública gerencial. Rio de Janeiro: Editora FGV, 2006.

RHODES, Roderick Arthur William. The new governance: governing without government. Political Studies, v. 44, n. 4, p. 652-667, 1996.

RHODES, Roderick Arthur William. Understanding governance: policy networks, governance, reflexivity and accountability. Philadelphia, US: Open University Press, 1997.

ROBERTSON, Susan; VERGER, Antoni. A origem das parcerias público-privadas na governança global da educação. Educação e Sociedade, Campinas, v. 33, n. 121, p. 1133-1156, 2012.

ROCHA, Carlos Vasconcelos. Ideias e formação de agenda de uma reforma educacional. Ensaio: Avaliação e Políticas Públicas em Educação, Rio de Janeiro, v. 19, n. 70, p. 191-218, mar. 2011

SOUSA, Sandra Maria Z. L.; OLIVEIRA, Romualdo P. Sistemas estaduais de avaliação: uso dos resultados, implicações e tendências. Cadernos de Pesquisa, São Paulo, v. 40, n. 141, p. 793-822, set./dez. 2010. 